\title{
POŠTA
}

TELEKOMUNIKACIE A

ELEKTRONICKY OBCHOD

elelsh

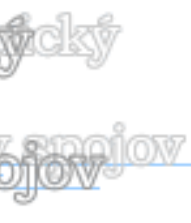

\section{BEZPEČNOSŤ A OCHRANA POŠTOVÝCH PREVÁDZOK}

\author{
Tomáš Loveček, Andrej Vel'as*
}

\section{Úvod}

Stratégiou poštovej bezpečnosti sa rozumie komplexné riešenie bezpečnostných opatrení vrátane definovania potenciálnych hrozieb, spracovanie návrhov a realizácia opatrení na včasné odstránenie hrozieb ako aj na ich zamedzenie. Stratégia poštovej bezpečnosti bola vypracovaná na základe čl. 9 Svetového poštového dohovoru a rezolúcií v oblasti poštovej bezpečnosti, boja proti terorizmu a $\mathrm{v}$ oblasti ochrany pred legalizáciou príjmov $\mathrm{z}$ trestnej činnosti a financovaním terorizmu v roku 2004. Obsahuje riešenie ochrany poštových subjektov pred trestnou činnost'ou formou investovania do preventívnych ochranných opatrení integrovatel'ných do bezpečnostného systému.

Bezpečnostný systém predstavuje integrovaný súbor reálnych prvkov, ktoré vytvárajú nástroj na zaistenie bezpečnosti $\mathrm{v}$ danom čase a priestore. Jednotlivé prvky bezpečnostného systému musia tvorit' synergický systém s ciel'ovým chovaním. Na vytvorenie bezpečnostného systému na zaistenie ochrany objektu (chráneného záujmu) sa využívajú najmä technické prostriedky ochrany (pasívne, aktívne), prvky fyzickej ochrany (Policajný zbor SR, súkromné bezpečnostné služby, atd'.) a organizačné a režimové opatrenia. Hlavným ciel'om bezpečnostného systému je zaistenie bezpečnosti, čo predstavuje stav, kedy je znížené ohrozenie na prijatel'nú mieru.

Každá poštová prevádzka má svoje určité špecifiká, ktorými sú napr. otváracia doba a z nej plynúce režimy, lokalita, vel'kost' objektu, členenie, situácia a d’alšie. Spoločným špecifikom sú predovšetkým prevádzkové režimy - denný a nočný prevádzkový režim. Počas tzv. denného režimu sú jej niektoré priestory prístupné širokej verejnosti, ktorá sa tam môže pohybovat' bez kontroly identity. Tomuto špecifiku je potrebné prispôsobit' aj jednotlivé prvky zabezpečenia.

Pasívne prvky ochrany sú tvorené mechanickými zábrannými prostriedkami rozdelenými na prvky obvodovej, pláštovej a predmetovej ochrany. V poštových prevádzkach sú používané posledné dve skupiny vo forme stavebných prvkov a otvorových výplní, bezpečnostných úschovných objektov a komerčných úschovných objektov.

V praxi sú zaužívané tri základné typy aktívnych prvkov ochrany: systémy kontroly a riadenia vstupov, kamerové bezpečnostné systémy a elektrické zabezpečovacie systémy spolu s tiesňovými poplachovými systémami. Prvý z nich je v podmienkach poštových prevádzok realizovatel'ný len pre kontrolu vstupov zamestnancov pri vstupe do vyhradených priestorov.

\footnotetext{
*Loveček Tomáš, doc. Ing., PhD., Fakulta špeciálneho inžinierstva, Katedra bezpečnostného manažmentu, Žilinská univerzita v Žiline, Ul. 1 mája 32, 01026 Žilina, e-mail: Tomas.Lovecek@fsi.uniza.sk Vel'as Andrej, Ing., PhD., Fakulta špeciálneho inžinierstva, Katedra bezpečnostného manažmentu, Žilinská univerzita v Žiline, Ul. 1 mája 32, 01026 Žilina, e-mail: Andrej.Velas@fsi.uniza.sk
} 
V ostatných priestoroch je systémy kontroly a riadenia vstupov t’ažké realizovat', nakol'ko poštová prevádzka je prístupná širokej verejnosti a nie len vyhradenej skupine klientov alebo občanov. Kamerový bezpečnostný systém je $\mathrm{v}$ súčasnosti využitel'ný nielen ako monitorovacie zariadenie schopné $\mathrm{v}$ prípade bezpečnostného incidentu poskytnút' vyšetrovatel'om materiál slúžiaci pri výsluchu zadržaného narušitel'a, ale nové technológie týchto systémov umožňujú aj samotnú detekciu narušitel'a v prípade narušenia stráženého priestoru (nočný režim), resp. automatickú on-line rekognoskáciu vstupujúcich osôb do priestorov pošty (denný režim). Avšak tieto kamerové systémy aj napriek svojmu dynamickému vývoju, stále neposkytujú 100\% garanciu detekcie narušitel'a (môže a nemusí byt' páchatel'om protiprávnej činnosti) počas nočného prevádzkového režimu. Preto je potrebné ich implementovat' $\mathrm{v}$ kombinácii s elektrickým zabezpečovacím systémom. Tento zabezpečovací systém umožňuje priame prepojenie, alebo obsahuje tiesňový poplachový systém, ktorý je neocenitel'ným nástrojom pre pracovníkov poštovej prevádzky počas dennej prevádzky $\mathrm{v}$ prípade nastania bezpečnostného incidentu. Taktiež umožňuje prepojenie jednotlivých poplachových systémov cez poplachovú prenosovú cestu na poplachové prenosové centrum prevádzkované obecnou/mestskou políciou, Policajným zborom SR alebo súkromnou bezpečnostnou službou.

\section{Aspekty projektovania elektrického zabezpečovacieho a tiesňového poplachového systému}

Elektrický zabezpečovací a tiesňový poplachový systém (EZS/TPS) je definovaný v norme STN EN 50131 ako poplachový systém na detekciu a indikáciu prítomnosti, vstupu alebo pokusu narušitel'a (vlamača) vstúpit' do chráneného priestoru.

Projektovanie zabezpečovacieho systému je činnost', ktorej ciel'om je navrhnút' systém, ktorý bude na základe informácií o zmene prostredia a systému samotného, adekvátne reagovat' na vzniknutú situáciu.

Podl'a zákona NR SR č. 473/2005 Z. z. o poskytovaní služieb v oblasti súkromnej bezpečnosti v znení neskorších predpisov patrí vývoj, výroba, predaj, projektovanie, montáž, údržba, revízia alebo oprava zabezpečovacích systémov alebo poplachových systémov a systémov a zariadení umožňujúcich sledovanie pohybu a konania osoby v chránenom objekte, na chránenom mieste alebo v ich okolí pod technickú službu na prevádzkovanie ktorej je potrebné vlastnit' licenciu. O udelení licencie na prevádzkovanie technickej služby rozhoduje Krajské riaditel'stvo Policajného zboru na základe žiadosti fyzickej osoby alebo právnickej osoby. Licencia na prevádzkovanie technickej služby sa vydáva na desat' rokov.[5]

Projektovanie zabezpečovacích a poplachových systémov sa týka troch subjektov, ktorými sú užívatel', projektant a prevádzkovatel'. Užívatel' využíva zabezpečovací systém k ochrane svojho, alebo zvereného majetku a záujmov. Pre užívatel'a systému je dôležitá jednoduchost' a pohodlnost' ovládania a užívatel'sky príjemné prostredie. Projektant navrhuje zabezpečovací systém na základe bezpečnostnej analýzy prostredia, pričom je zodpovedný za vhodnost' a reálnost' riešenia, ekonomickú efektívnost' a uvedenie systému do prevádzky. Prevádzkovatel' je spoluzodpovedný za bezporuchovú prevádzku zabezpečovacieho systému za podmienok dohodnutých s užívatel'om. Pri samotnej realizácii musí elektrický zabezpečovací systém spĺn̆at' požiadavky na funkčnost' a spol'ahlivost' uvedené v norme STN EN 50131.

Pri projektovaní zabezpečovacích a poplachových systémov je potrebné realizovat' bezpečnostnú analýzy objektu, ktorej ciel’om je oboznámit' sa s objektom, jeho usporiadaním 
a okolím (prístupovými cestami, blízkymi obydliami, atd'.). Ďalej je potrebné zistit' zranitel’né miesta, ako aj možné spôsoby napadnutia objektu a to z vonkajšieho a vnútorného prostredia.

Pri návrhu elektrického zabezpečovacieho a tiesňového poplachového systému je vhodné získat' kópiu stavebnej výkresovej dokumentácie objektu, alebo aspoň základné nákresy.

Na základe stavebnej dokumentácie je potrebné zhodnotit' súčasný stav objektu a to klasické zabezpečenie, dislokáciu objektu k okolitým objektom a pravdepodobnost' vlámania sa do objektu. Pri posudzovaní pravdepodobnosti vlámania sa do objektu sú posudzované tieto faktory: druh majetku, atraktívnost' pre páchatel'a, hodnota majetku, objem a vel'kost' majetku, jednoduchost' krádeže a odvozu ukradnutého majetku, riziko poškodenia vandalmi a pod.

Pri posudzovaní súčasného stavu budovy sú dôležité tieto faktory: lokalita a poloha objektu, konštrukcia budovy, plášt' budovy a pláštové otvory (dvere, okná, ventilačné šachty), personál, kl'účový režim, súčasné zabezpečenie, história krádeží, vlastná legislatíva a predpisy, vplyvy pôsobiace na zabezpečovacie systémy.

Pri samotnom návrhu EZS/TPS poštovej prevádzky je potrebné brat' do úvahy tieto špecifiká: poplachový prenosový systém by mal byt' riešený aspoň dvomi poplachovými prenosovými cestami (GPRS, GMS, WIFI, JTS, prípadne iné).Podl'a rozsahu poštových prevádzok je možné uvažovat' o tom, či systém bude drôtový, bezdrôtový, alebo hybridný. Podla režimov jednotlivých pracovísk je možné systém rozdelit' na zóny, kde vybrané miestnosti môžu byt' strážené aj počas pracovnej doby za prítomnosti zamestnancov v prevádzkových miestnostiach.

Systém EZS obsahuje komponenty znázornené na nasledujúcom obrázku.

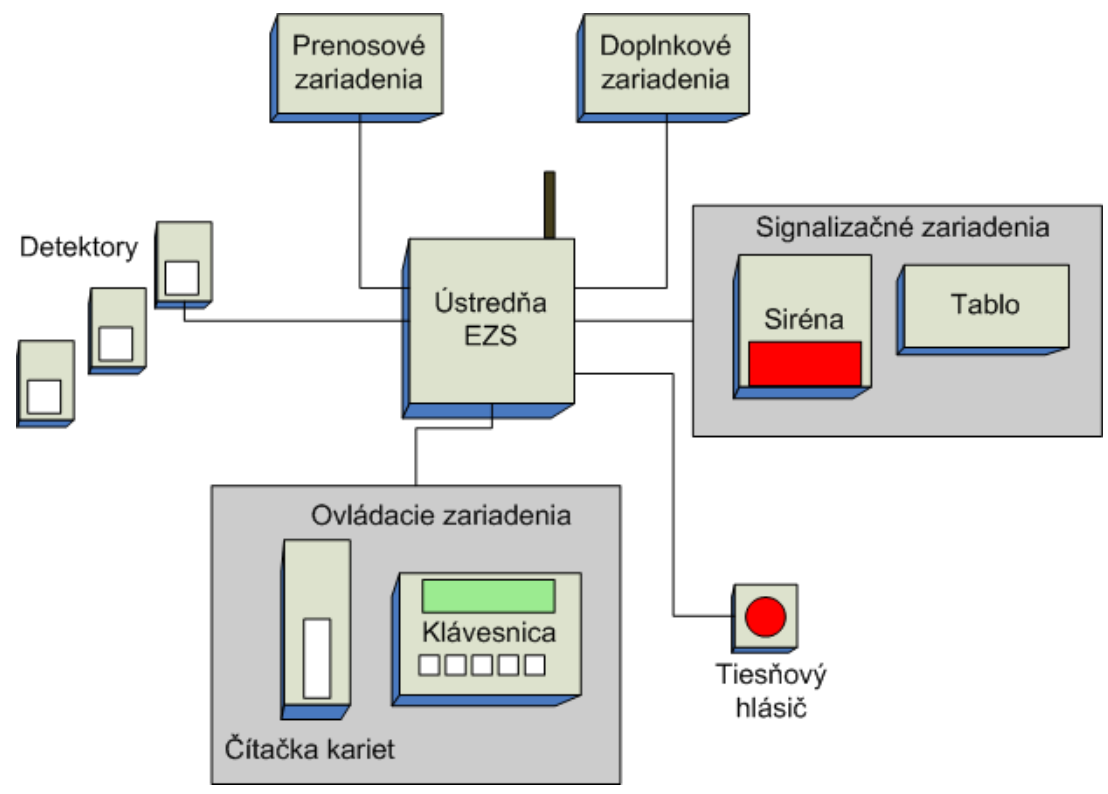

Obr. 1 Zjednodušená schéma EZS [5]

Pre inštaláciu jednotlivých komponentov platia určité zásady, ktoré je možné v krátkosti popísat' a aplikovat' na poštové prevádzky:

Ústredňa EZS musí byt' umiestnená vo vnútri chráneného priestoru v priestore s najvyšším stupňom zabezpečenia. Prepojovacie káble musia zodpovedat' požadovanému 
prevedeniu systému. Je potrebné dbat', aby nedošlo k vzájomnému vedeniu káblov s elektrickým vedením (možné rušenie).

Pri bezdrôtových prenosoch je potrebné brat' v úvahu rádiové prenosy, ktoré môžu rušit' vysielanie. Detektory pohybu môžu byt' ovplyvnené predmetmi pred priezorom detektora, prievanmi, vykurovacími telesami, osvetlením snímacích častí slnečnými lúčmi, atd'.

Magnetické detektory otvorenia okien musia byt' umiestnené tak, aby nedošlo k ich úmyselnému poškodeniu. Akustické detektory rozbitia skla nie je vhodné montovat' v hlučnom prostredí, prípadne v prostredí kde sú generované zvuky telefónneho zvonenia. Detektory dymu sa inštalujú prevažne na strop a ich inštalácia nie je vhodná do vlhkých, alebo prašných priestorov. Pre pošty dôležité tiesňové hlásiče slúžia pre privolanie pomoci. Musia byt' l'ahko dostupné, ale umiestnené tak, aby nedošlo k náhodnej aktivácii. Použitie interiérovej sirény $\mathrm{v}$ poštových prevádzkach je vhodné len v priestoroch, kde je predpoklad, že odradí páchatel'a od zotrvania v priestore húkajúcej sirény. Vonkajšia siréna má za úlohu upozornit' na pokus o vlámanie, ale táto forma signalizácie má pomerne malú účinnost'[4].

Účinnost' systému je závislá na rýchlom a adekvátnom zásahu bezpečnostnej služby, preto by mala byt' každá pošta pripojená na pult centralizovanej ochrany. Problematické je riešenie fyzickej ochrany objektov pôšt, kde je čas zásahu zásahovej jednotky (Policajného zboru SR, prípadne SBS) dlhší ako čas realizácie samotného lúpežného prepadnutia.

Pre prenos poplachového signálu je vhodné použit' aspoň dve nezávislé poplachové prenosové cesty.

\section{Aspekty projektovania kamerového bezpečnostného systému}

Kamerové bezpečnostné systémy (priemyselná televízia - PTV) v súčasnosti zaznamenávajú najväčší rozvoj z jednotlivých aktívnych prvkov technickej ochrany. PTV je systém, ktorý obsahuje kamerovú zostavu, zobrazovacie a d’alšie prídavné zariadenie potrebné na prenos signálu a obsluhu pri sledovaní definovanej bezpečnostnej zóny [1]. Medzi jeho základné funkcie patrí:

- detekcia narušenia stráženého priestoru na základe monitorovania v reálnom čase strážnou službou, resp. zásahovou jednotkou,

- automatická detekcia narušenia stráženého priestoru prostredníctvom prednastavených detekčných zón priamo v kamere alebo vyhodnocovacom zariadení (napr. multiplexor),

- vykonávanie záznamu snímaného obrazu z dôvodu neskoršieho spracovania (napr. identifikácia osôb a vozidiel),

- verifikácia príčiny poplachu spôsobeného iným poplachovým systémom (napr. EZS).

Kamerový bezpečnostný systém pozostáva z/zo:

- kamier a ich príslušenstva (napr. optický snímač, objektív, kryt, napájanie, polohovacie hlavice, konzoly, prostriedky prepät'ovej ochrany, IR alebo halogénové reflektory),

- zariadení na prenos a riadenie videosignálu (napr. kvadrátory, multiplexory, deliče obrazu, kabeláž, switch, router, web server, bezdrôtové vysielače/prijímače, ovládacie klávesnice - PTZ),

- záznamového a zobrazovacieho zariadenia (napr. analógový alebo digitálna videorekordér, projekčné/LCD monitory, farebné/čiernobiele obrazovky). 
Základným a najdôležitejším prvkom kamerového systému je kamera, ktorá sníma obraz sledovanej scény a svetelnú energiu odrazenú od predmetov v ich zornom poli prevádza na elektrické signály. Tieto signály sú určené na prenos a d'alšie spracovanie (napr. vyhodnotenie narušenia stráženého priestoru). Základnou čast'ou bezpečnostnej kamery je optický snímač, ktorý premieňa dopadajúce svetlo na elektrický signál. Snímač musí byt' doplnený o optický systém (objektív), ktorý zaistí, aby svetlo dopadlo na svetlocitlivú plochu v potrebnej kvalite. Kamerové bezpečnostné systémy nie sú rozdelené na jednotlivé stupne zabezpečenia, tak ako je to v prípade systémov EZS. Preto je potrebné venovat' vyššiu pozornost' vol'be parametrov jednotlivých systémových komponentov. Medzi základné parametre optického snímača, ktoré je potrebné brat' do úvahy pri navrhovaní ochranného systému patrí technológia optického snímača (napr. DPS, CCD, CMOS), spôsob snímania (prekladané skenovanie, optické skenovanie), vel'kost' a rozlíšenie optického snímača (napr. 1/2”, 1/3", 1/4"), rozlišovacia schopnost' (napr. 320x 200, 640x480), dynamický rozsah (EV), odstup signálu od šumu (S/N) a spôsob synchronizácie (interná, externá, od napájacej siete). Dôležitá je aj vol'ba parametrov objektívu, medzi ktoré patrí uchytenie objektívu (C/CS), ohnisková vzdialenost', svetelnost', citlivost', vlnový rozsah, clona, možnost' nastavenia clony a ohniskovej vzdialenosti. Navyše je potrebné uvažovat' aj nad d'alšími špeciálnymi funkciami kamier, ako napríklad funkcia elektronickej uzávierky, funkcia udržujúca výstupný videosignál na konštantnej úrovni, eliminácia protisvetla, bodová kompenzácia protisvetla, automatické vyváženie bielej, rozšírené automatické sledovanie bielej, maskovanie privátnych zón, detekcia pohybu, kompresia obrazu alebo zamrazenie snímku. Vol'ba týchto parametrov závisí od základných prevádzkových požiadaviek daného subjektu (napr. prevedenie kamerového systému analógový/digitálny/hybridný systém, doba a čas prevádzky, prostredie prevádzky, potreby používatel'ov obrazovej produkcie) [3].

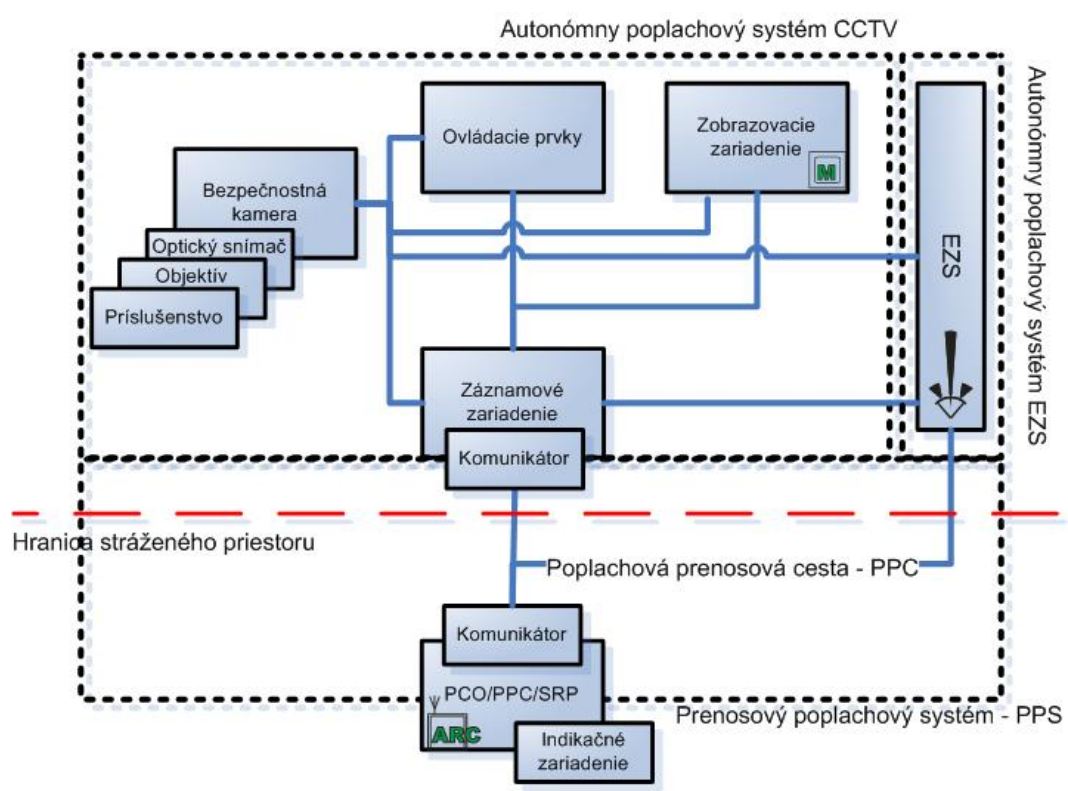

Obr. 2 Bloková schéma poplachového systému tvoreného EZS a CCTV (vlastné spracovanie)

Kamerové systémy v prvopočiatkoch boli určené bud' na neskoršiu identifikáciu narušitel'a, alebo na sprostredkované vizuálne overenie správnosti poplachového stavu zásahovou jednotkou. V súčasnosti kamerové systémy už slúžia aj na vyvolanie poplachového stavu bez samotnej on-line účasti operátora. To im umožňuje funkcia MDS (angl.: Motion Detection System) implementovaná v samotnej kamere alebo vyhodnocovacej jednotke (napr. multiplexor), ktorá na základe zmeny stavu snímaného obrazu vyvoláva poplachový stav. Problémom však ostáva skutočnost', že výrobcovia/predajcovia neuvádzajú parametre 
snímanej stopy $\mathrm{v}$ závislosti na pravdepodobnosti detekcie narušitel'a, tak ako tomu je v prípade charakteristík detektorov EZS. Dôvodom prečo je to tak, by mohla byt' tá skutočnost', že parametre snímanej stopy sú závislé od viacerých činitel'ov, ako je napríklad rozmer optického snímača, svetelné podmienky a typ objektívu.

Vo vzt'ahu k snímanej scéne môžeme uvažovat' o dvoch typoch monitorovania (Obr. 3). Ide o tzv. lokálne monitorovanie, kde footprint kamery má tvar lichobežníka a horizont snímanej scény je ohraničený (napr. monitorovanie vstupu do pošty). Tento typ monitorovania je charakteristický tým, že horná hranica snímaného obrazu je v uhle menšom ako $90^{\circ}$ k nosnej konštrukcii (napr. múr, stĺp, stožiar, plot). Druhým možným typom monitorovania je tzv. priestorové monitorovanie, ktoré nemá ohraničený horizont snímanej scény. Tento typ monitorovania je charakteristický tým, že horná hranica snímaného obrazu je minimálne v pravom alebo tupom uhle k nosnej konštrukcii (napr. pri snímaní prístupových ciest k poštovej prevádzke).
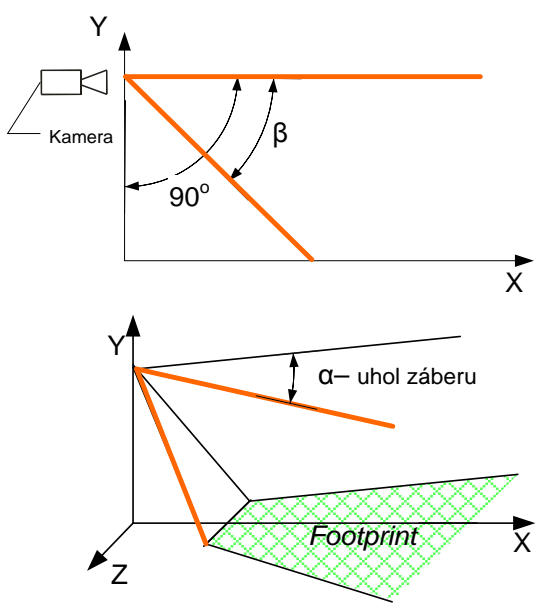

a)
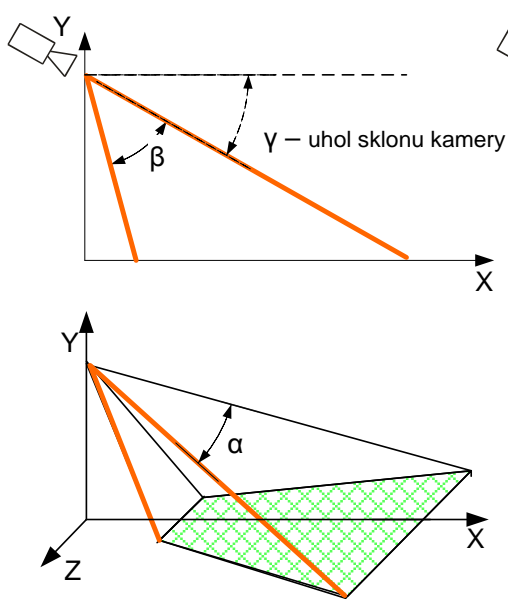

b)

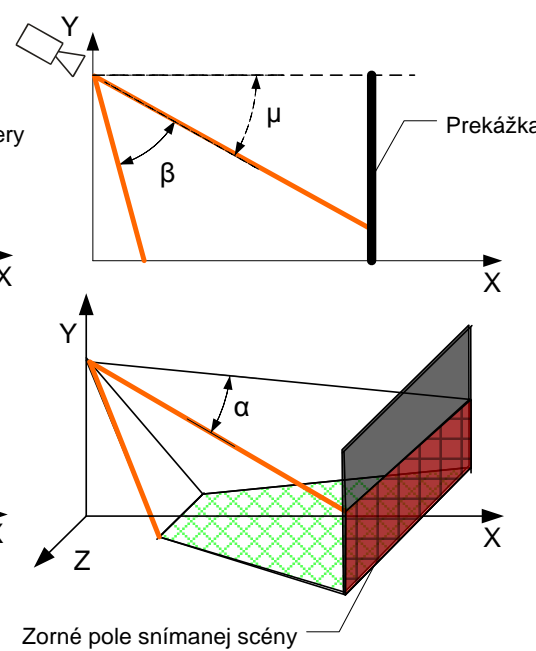

c)

Obr. 3 a) Priestorové monitorovanie b) Lokálne monitorovanie c) Lokálne monitorovanie blokované prekážkou (vlastné spracovanie)

Každé z oboch monitorovaní má svoje určité špecifikum. Pri lokálnom monitorovaní je potrebné rátat' s tým, že narušitel' v prípade vstúpenia do monitorovanej zóny obvykle vyvolá poplachový stav, ale nemusí byt' možná jeho prípadná identifikácia. Samotnou problematikou dodatočnej identifikácie narušitel'a sa budeme zaoberat' neskôr. V prípade priestorového monitorovania je potrebné počítat' s dlhším časom reakcie poplachového systému (napr. až do okamžiku, kedy postava narušitel'a bude predstavovat' spomínaných 10\% snímanej scény). Pri oboch typoch monitorovaní môže dôjst' k situácii, kedy je zorné pole snímanej scény obmedzené nepriehl'adnou prekážkou (napr. stena, plot, protil'ahlá budova).

Pri priestorovom monitorovaní dochádza k situácii, kedy sa snímané scény jednotlivých kamier vzájomné prelínajú a kamery vytvárajú tzv. obvodové priestorové monitorovanie.

V prípade použitia kamerového systému je dôležitá úloha obsluhy kamerového systému a vyhodnocovania záznamov. Kamerový bezpečnostný systém môže byt' obsluhovaný len pracovníkmi súkromnej bezpečnostnej služby, prípadne vyhodnocovaný Policajným zborom a nemôže slúžit’ na monitoring činnosti zamestnancov, čo ukladá zákon o súkromnej bezpečnosti. 


\section{Záver}

Kamerové systémy a elektrické zabezpečovacie a tiesňové poplachové systémy sú často implementované v poštových prevádzkach. Častým problémom v oblasti prevádzky kamerových systémov je rozpoznatel'nost' prípadného narušitel'a zachyteného kamerou, čo je následkom benevolentnosti firiem pri projektovaní týchto systémov. Problémom v oblasti elektrických zabezpečovacích systémov je reakčný čas zásahovej jednotky, ktorý v mnohých prípadoch nie je zohl'adňovaný a nie je dostatočný na zadržanie páchatel'a na mieste činu.

Technické zabezpečenie poštových prevádzok je vzhl'adom na ich činnost' a hodnoty s ktorými pošty nakladajú dôležitým a nenahraditel'ným prvkom ochrany týchto objektov. Akékol'vek technické zabezpečenie je závislé od l'udského potenciálu. Plán ochrany objektov poštových prevádzok by mal byt' realizovaný bezpečnostným manažérom s dostatočnými skúsenost’ami a vzdelaním v danej oblasti.

Spol'ahlivost' technických zariadení použitých pri ochrane objektov závisí od odbornosti obsluhy, preto vhodné, aby boli zamestnanci zaškolení, čím by sa minimalizovali straty a škody vznikajúce nesprávnou obsluhou. Školenia bezpečnostných manažérov i radových zamestnancov v oblasti bezpečnostných systémov ponúka formou rôznych kurzov aj Katedra bezpečnostného manažmentu na Fakulte špeciálneho inžinierstva ŽU.

\section{Literatúra}

[1] STN EN 50132-7 (33 4592) Poplachové systémy. Sledovacie systémy CCTV na používanie v bezpečnostných aplikáciách. Čast' 7: Pokyny na používanie.

[2] GOŇA, S., LOVEČEK, T.: Detekcia narušitel'a poplachovými systémami a nové bezpečnostné technológie zvyšujúce jej pravdepodobnost'. In: Zborník z medzinárodnej bezpečnostnej konferencie „Perspektívni bezpečnostni technologie ochrany majetku“. Brno, 2008. ISBN 978-80-7318-699-9.

[3] LOVEČEK, T.: Bezpečnostné systémy - Kamerové bezpečnostné systémy. EDIS vydavatel'stvo ŽU v Žiline, 2008. ISBN 978-80-8070-893-1

[4] Poplachové systémy - Pravidlá zriad'ovania elektrických zabezpečovacích systémov v objektoch. Podniková norma PNJ 131 Jablotron. Vydaná spoločnost'ou Jablotron v júni 2008.

[5] VEL'AS, A.: Elektrické zabezpečovacie systémy - ich aplikácie do inteligentných budov. In: Bezpečnostni workshop , Vliv technologii inteligentnich budov na zajištěení bezpečnosti objektư “. Pragoalarm 26.2.2009. Praha, Univerzita Tomáše Bati ve Zlíně, FAI, 2009. recenzovaná, pozvaná prednáška, 6s. ISBN 978-80-7318-799-6

[6] MACH, V.: Ochrana majetku mechanickými zábrannými prostriedkami. In.: Zborník vedeckých prác. VI. medzinárodná konferencia: „Bezpečnost' života a činnosti l'udí, vzdelávanie, veda, prax“, Akadémia bezpečnosti a základov zdravia, Kyjev 2007, str. 59, ISBN 966-96344-2-3

[7] Stratégia poštovej bezpečnosti. Citované 15.3.2013. Dostupné on-line na: http://www.telecom.gov.sk/index/index.php?ids=55181

[8] Výkladový slovník terminológie bezpečnostného manažmentu. Pojem bezpečnostný systém. Citované 17.3.2013. Dostupné on-line na: http://www.securityrevue.com/tbm/part1_b.html\#bezpecnostny-system 
[9] PROTIVINSKY, M. a kol.: Bankové loupeže. Praha: Trivis, 2001. ISBN 80-86244-210

[10] STN EN 50131 Poplachové systémy. Elektrické zabezpečovacie a tiesňové poplachové systémy. Časti 1 až 8. 